\title{
SCHUM v. SOUTH BUFFALO RAILWAY: UNINTENTIONAL UNION FAILURE TO PROCESS GRIEVANCE CONSTITUTES BREACH OF UNION'S DUTY OF FAIR REPRESENTATION
}

In Schum v. South Buffalo Railway, ${ }^{1}$ a case which arose under the Railway Labor Act, ${ }^{2}$ the Second Circuit Court of Appeals held that an unintentional failure by a union to prosecute a timely appeal to the National Railroad Adjustment Board ${ }^{3}$ on behalf of a union meniber discharged front employnent constituted a breach of the union's duty of fair representation, ${ }^{4}$ which excused the aggrieved member's failure to pursue his administrative remedies. Janies Schun, the union member, was discharged from employment by the South Buffalo Railway after failing to report for a scheduled physical examination and then failing to appear at a disciplinary hearing convened to consider his failure to report for the examination. ${ }^{5}$ Upon Schum's request for assistance, the General Chairman of his local umion agreed to process a grievance on Schum's behalf. A written complaint, the required first step in the grievance procedure, ${ }^{6}$ was filed with the railroad and was rejected. The

1. 496 F.2d 328 (2d Cir. 1974).

2. 45 U.S.C. $\$ \$ 151$ et seq. (1970).

3. The National Railroad Adjustment Board was created by section 3 First of the Railway Labor Act, 45 U.S.C. $\$ 153$ First (1970), for the purpose of settling disputes and grievances growing out of the interpretation and application of collective bargaining agreements. For further discussion of the Adjustment Board, see text accompanying notes 12-22 infra.

4. For a discussion of the duty of fair representation, see text accompanying notes 31-41 infra.

5. Schum was ordered by the railroad to report for a physical examination in order to resolve a dispute over whether he was physically capable of resuming his regular duties after six months of recuperation from personal injuries received in the course of his employment. 496 F.2d at 329.

The positions of the parties to this dispute are not clear from a reading of the opinion and the briefs. Schum's nonappearance for the physical was apparently occasioned by the railroad's refusal to allow his attorney to be present. He allegedly did not appear at the disciplinary hearing because the railroad refused to postpone the hearing until Schum's attorney returned from vacation. Brief for Appellant at 5-6, Schum v. South Buffalo Ry., 496 F.2d 328 (2d Cir. 1974).

6. Under the Railway Labor Act, the details of an individual grievance adjustment procedure are stipulated by the union and employer in their collective bargaining agreement, subject to the requirement of section 3 First(i) of the Act that the grievance must be processed to the chief management representative designated for the handling of such disputes. This requirement must be satisfied prior to an appeal to the National Railroad Adjustment Board. 45 U.S.C. § 153 First(i) (1970). 
next step, as stipulated in rule 36 of the collective bargaining agreement between the union and the railroad, would have been the filing of an appeal with the National Railroad Adjustment Board by the aggrieved employee or his union within six months of rejection of the complaint. ${ }^{7}$ The union not only failed to file an appeal but also neglected to inform Schum that his appeal would not be processed. ${ }^{8}$ When Schun1 learned that his umon had allowed his right to administrative review to expire without acting, he filed an action in federal district court against the railroad for wrongful discharge ni violation of the collective bargaining agreement and against three umion defendants ${ }^{0}$ for breach of their duty of fair representation. The railroad moved for and obtained sun1mary judgment on the ground that plaintiff had failed to exhaust his administrative remedies. ${ }^{10}$ The Second Circuit reversed and remanded. ${ }^{11}$

7. Section $b$ of rule 36 of the collective bargaining agreement provided, in pertinent part:

All clains or grievances involved in a decision of the highest officer [designated by the Company to handle claims and grievances] shall be barred unless within 6 inonths from the date of his decision proceedings are instituted by the Employee or his duly authorized representative before a tribunal having jurisdiction pursuant to law or agreement of the claim or grievance involved. 496 F.2d at 331 n.3.

8. The failure of the union to file a timely appeal with the Adjustment Board is not explained in the opinion or in the appellate brief of either party. The failure was apparently unintentional. Significantly, Schum does not appear to have alleged hostility or bad faith as the motivation for the union's failure.

9. Schum's union was the United Transportation Union. In addition to the employer railroad, Schum sued the national union, his local union (John O'Leary Lodge E668, formerly a local of the Brotherhood of Locomotive Firemen and Enginemen), and the General Chairman of the local. Brief for Appellee at 1, Schum v. South Buffalo Ry., 496 F.2d 328 (2d Cir. 1974).

The umion defendants joined in the railroad's motion for summary judgment, see note 10 infra and accompanying text, but did not file a brief or participate in the oral argument. Schuin v. United Transp. Union, Lodge E668, Civil No. 1970-11, at 2 (W.D.N.Y. Aug. 1, 1973).

10. The district court granted the railroad's motion for summary judgment but denied the motion of the union defendants. Schum v. United Transp. Union, Lodge E668, Civil No. 1970-11, at 8 (W.D.N.Y. Aug. 1, 1973). This result, though it left Schum with the union defendants to proceed against, would be unsatisfactory to Schum because of the severe limitation imposed by the Supreme Court on recovery of damages from a union for breach of its duty of fair representation in Czosek v. O'Mara, 397 U.S. 25 (1970), where the Court held:

Assuming a wrongful discharge by the employer independent of any discriminatory conduct and a subsequent discriminatory refusal by the union to process grievances based on the discharge, damages against the union for loss of employment are unrecoverable except to the extent that its refusal to handle the grievances added to the difficulty and expense of collecting from the einployer. Id. at 29.

See also Vaca v. Sipes, 386 U.S. 171, 196-98 (1967).

11. The appellate court directed that "if the district court finds on remand that Schum reasonably relied on his union to prosecute his grievance, the railroad's defense 
Among the express purposes listed by Congress upon amendment of the Railway Labor Act in $1934^{12}$ was an intent to facilitate the resolution of disputes and grievances growing out of the imterpretation and application of collective bargaining agreennents. ${ }^{13}$ This category of dispute is commonly known as a "minor" dispute, ${ }^{14}$ and includes discliarge grievances. ${ }^{15}$ By the 1934 amendment, ${ }^{16}$ the National Railroad Adjustment Board was created and given jurisdiction to decide these minor disputes. ${ }^{17}$ Resort to the Adjustment Board has been held by the courts

of nonexhaustion would not bar his wrongful discharge suit." 496 F.2d at 332 . Thus, assuming a finding that Schum reasonably relied on his union, the district court will decide the case on the merits of Schum's claim of wrongful discharge.

12. Act of June 21, 1934, Pub. L. No. 73-442, ch. 691, \& 2, 48 Stat. 1186-87, amending 48 U.S.C. $\$ 151$ (1928) (codified at 45 U.S.C. $\$ 151$ (a) (1970)).

13. The purposes of the chapter are: ... (5) to provide for the prompt and orderly settlement of all disputes growing out of grievances or out of the interpretation or application of agreements covering rates of pay, rules, or working conditions. 45 U.S.C. $\$ 151$ (a) (1970).

14. The courts have adopted the designation of disputes arising under the Railway Labor Act as "minor" and "major." See Elgin, J. \& E. Ry. v. Burley, 325 U.S. 711, 723 (1945). Major disputes relate to the formation or alteration of the terms of a collective bargaining agreement rather than to the interpretation and application of an existing agreement. Major disputes are not subject to binding resolution, as are minor disputes, and work stoppages may result if the parties are unable to resolve their differences with the assistance of the National Mediation Board, another agency created by the Railway Labor Act. 45 U.S.C. $\$ 154$ (1970). For further discussion of the handling of major and minor disputes and the potential difficulty in distinguishing the two, see Risher, The Railway Labor Act, 12 B.C. IND. \& CoM. L. REv. 51, $57-85$ (1970).

15. Walker v. Southern Ry., 385 U.S. 196, 198 (1966).

16. Act of June 21, 1934, Pub. L. No. 73-442, ch. 691, 48 Stat. 1185, amending 45 U.S.C. $\S \S 151-88$ (1928) (codified at 45 U.S.C. $\$ \$ 151-88$ (1970)).

17. Section 3 First(i) of the Railway Labor Act, 45 U.S.C. \& 153 First(i) (1970), provides:

The disputes between an employee or group of employees and a carrier or carriers growing out of grievances or out of the interpretation or application of agreements concerning rates of pay, rules, or working conditions, including cases pending and unadjusted on June 21,1934 , shall be handled in the usual manner up to and including the chief operating officer of the carrier designated to handle such disputes; but, failing to reach an adjustment in this manner, the disputes may be referred by petition of the parties or by either party to the appropriate division of the Adjustment Board with a full statement of the facts and all supporting data bearing upon the disputes.

Prior to 1934, minor disputes were handled by over 300 arbitration boards, most of which were limited in jurisdiction to a single railroad. This diffuse approaeh to minor disputes proved unworkable for a number of reasons. See Garrison, The National Railroad Adjustment Board: A Unique Administrative Agency, 46 YALE L.J. 567, 57376 (1937).

In considering the 1934 Amendments, the House Committee on Interstate Commerce stated:

Many thousands of these disputes have been considered by boards established under the Railway Labor Act; but the boards have been unable to reach a majority decision, and so the proceedings have been deadlocked. These unadjusted disputes have become so numerous that on several occasions the employees have resorted to the issuance of strike ballots and threatened to interrupt interstate cominerce in order to secure an adjustment. This has made it 
to be the mandatory and exclusive remedy when a minor dispute is not resolved between the parties. ${ }^{18}$ In Andrews v. Louisville \& Nashville Railroad ${ }^{19}$ the Supreme Court affirmed a lower court's dismissal of an employee's action against his employer for wrongful discharge on the ground that plaintiff-employee had failed to pursue his administrative remedy before the Adjustment Board. This remedy provided by the Railway Labor Act for settlement of minor disputes is not optional, the Court ruled, but mandatory. ${ }^{20}$ Furthermore, the Court explained that the phrase "exhaustion of remedies" applies to the settlement of minor disputes under the Railway Labor Act only "in its broader sense" because the administrative remedy is exclusive. ${ }^{21}$ Thus, an aggrieved party must take his dispute to the Adjustment Board and may not litigate the dispute in state or federal court. Review of a decision of the Adjustment Board is limited to the judicial review provided by the Railway Labor Act. ${ }^{22}$

necessary for the President of the United States to intervene and establish an emergency board to investigate the controversies. This condition should be corrected in the interest of industrial peace and of uninterrupted transportation service. This bill, therefore, provides for the establishment of a national board of adjustment to which these disputes may be submitted if they shall not have been adjusted in conference between the parties. H.R. REP. No. 1944, 73d Cong., 2d Sess. 3 (1934), quoted in Elgin, J. \& E. Ry. v. Burley, 325 U.S. 711, 726 n.22 (1945).

18. See Andrews v. Louisville \& N.R.R., 406 U.S. 320 (1972); Brotherhood of R.R. Trainınen v. Chicago R. \& I.R.R., 353 U.S. 30 (1957); Slocnm v. Delaware, L. \& W.R.R., 339 U.S 239 (1950); Order of Ry. Conductors v. Pitney, 326 U.S. 561 (1946); Local 1477, United Transp. Union v. Baker, 482 F.2d 228 (6th Cir. 1973); Baker v. United Transp. Union, 455 F.2d 149 (3d Cir. 1971); Brotherhood of Locomotive Firemen \& Enginemen v. Southern Pac., 447 F.2d 1127 (5th Cir. 1971).

19. 406 U.S. 320 (1972).

20. Id. at 322 .

21. Id. at 325. The phrase "exhaustion of administrative remedies," in its usual sense, refers to the requirement that administrative remedies must be pursned to completion before judicial review may be sought. See K. Davis, Administrative Law Text $\S 20.01$ (3d ed. 1972). The statement by the Andrews Court that "exhanstion of remedies" applies "in a broader sense," 406 U.S. at 325, means that decisions of the National Railroad Adjustment Board are not reviewable. Thus, when a party's administrative remedy is exhausted he has no fnrther remedy unless the Board exceeded its authority. The basis of this "nonreviewability" is the statutory restriction embodied in the Railway Labor Act. See note 22 infra. See also K. DAvis, supra, \$§ 28.01-07.

22. 45 U.S.C. $\$ \S 153$ First(p), (q) (1970). The judicial review provision of Section 3 First was amended in 1966 because Congress found that

if an employee receives an award in his favor from the Board, the railroad affected may obtain judicial review of that award by dechining to coinply with

it. If, however, an employee fails to receive an award in his favor, there is no means by which judicial review may be obtained. H.R. REP. No. 1114, 89th Cong., 1st Sess. 15, quoted in Walker v. Southern Ry., 385 U.S. 196, 198 (1966).

As amended in 1966, Section 3 First(p) now makes an order of the Adjustment Board "conclusive on the parties," in a snit for enforcement rather than merely "prima facie evidence of the facts therein stated." Section 3 First(q) was added to provide judi- 
There are exceptions to the mandatory and exclusive administrative remedy provided by the Railway Labor Act for the resolution of minor disputes; under certain circumstances an employee may bring an action against his employer in federal court rather than before the Adjustment Board. In the landmark case of Vaca v. Sipes, ${ }^{23}$ which arose under the National Labor Relations Act, ${ }^{24}$ the Supreme Court identified several situations which would justify an employee's failure to exhaust his contractual and administrative remedies. Employer repudiation of the grievance procedure will justify direct resort to the courts, ${ }^{25}$ as will a breach by the umion of its duty of fair representation in the handling of a grievance. ${ }^{20}$ The Court specifically identified the situation of a hostile union's wrongful refusal to process a grievance where it has complete control of a member's right to grieve, ${ }^{27}$ but since this situation cannot arise under the Railway Labor Act, ${ }^{28}$ it seems that the Vaca Court's blanket exception for a union breach of the duty of fair representation must also include the case where the union does not control the grievance

cial review of the order for the losing party, but it reiterates that the order shall be "conclusive on the parties" and may not be set aside except for failure by the Board to comply with the statute, failure of jurisdiction, or corruption. Act of June 20, 1966, Pub. L. No. 89-456, $\$ \$ 2(c),(e), 80$ Stat. 210, amending 45 U.S.C. $\$ 153$ (1964) (codificd at 45 U.S.C. $\$ \$ 153$ First (p), (q) (1970)).

23. 386 U.S. 171 (1967).

24. 29 U.S.C. $\$ \$ 151$ et seq. (1970).

25. The Court explained where this action would be appropriate: "An obvious situation in which the employee should not be limited to the exclusive remedial procedures established by the contract occurs when the conduct of the employer amounts to a repudiation of those contractual procedures." 386 U.S. at 185.

26. The Vaca Court said:

[W]e think the wrongfully discharged employee may bring an action against his employer in the face of a defense based upon the contractual remedies, provided the employee can prove that the union as bargaining agent breached its duty of fair representation in its handling of the employee's grievance. Id. at 186 .

27. The Vaca Court observed:

We think that another situation when the employee may seek judicial enforcement of his contractual rights arises if, as is true here, the union has sole power under the contract to invoke the higher stages of the grievance procedure, and if, as is alleged here, the employee-plaintiff has been prevented from exhausting his contractual remedies by the union's wrongful refusal to process the grievance. Id. at 185 .

28. The Supreme Court has held that the Railway Labor Act grants to the employee the right to participate at every stage of the grievance adjustment process and to process his grievance independently of his union. Elgin, J. \& E. Ry. v. Burley, 325 U.S. 711, 733-36 (1945). These rights are statutory and may not be abrogated by agreement between the employer and the union. Id. at 740 n.39.

In contrast, the National Labor Relations Act permits the employer and the union to retain exclusive control of the grievance procedure. Black-Clawson Co. v. International Ass'n of Machinists, 313 F.2d 179 (2d Cir. 1962). See also Vaca v. Sipes, 386 U.S. 171, 185 (1967); Republic Steel v. Maddox, 379 U.S. 650, 652-53 (1965). For the Court's specific language in Vaca, see note 27 supra. 
process. In Glover v. St. Louis-San Francisco Railway, ${ }^{29}$ the Vaca holding was applied to a case arising under the Railway Labor Act. The Court ruled that a group of railroad carmen helpers, who alleged they were denied promotion on the basis of race through the collusion of their employer and their union, could pursue their remedy in federal court rather than before the Adjustment Board. ${ }^{30}$ Thus, it is clear from Vaca and Glover that a railroad employee whose union breaches its duty of fair representation in handling his grievance can sue in federal court, and his action will not be summarily disposed of for failure to pursue his administrative remedy before the Adjustınent Board. The question left partially unanswered by $\mathrm{Vaca}$ is precisely what may constitute a breach of the union's duty of fair representation.

The concept of a union's duty of fair representation was first articulated by the Suprene Court in Steele v. Louisville \& Nashville Railroad. $^{31}$ The union in Steele sought to negotiate an agreenient with the employer which would have precluded the promotion and further hiring of black firemen, and it had concurred in work assignments which favored white firemen over black firemen with greater seniority. The Court ruled that the union's behavior violated a duty of representation implicit in the Railway Labor Act. ${ }^{32}$ Having previously construed the Railway Labor Act and the National Labor Relations Act as conferring upon unions the status of exclusive bargaining representative for all members of the bargaining unit, ${ }^{33}$ the Court in Steele found a correlative

29. 393 U.S. 324 (1969).

30. The Court created a new exception to the exhaustion requirement in Glover: an aggrieved employee need not exhaust his contractual or administrative remedies where to do so would be futile. Id. at 330 . Further, the Glover Court acknowledged the possible existence of further exceptions to the exhaustion requirement when it observed that

[t]he Court in Vaca went on to specify at least two situations in which suit could be brought by the employee despite his failure to exhaust fully his contractual remedies. The circumstances of the present case call into play another of the most obvious exceptions to the exhaustion requirement . . . I Id. (emphasis added).

At least one commentator has interpreted the Glover opinion as an invitation to the lower federal courts to create new exceptions to the exhaustion requirement. See Simpson \& Berwick, Exhaustion of Grievance Procedures and the Individual Employee, 51 TEXAS L. Rev. 1179, 1212-13 (1973).

31. 323 U.S. 192 (1944).

32. The Court stated:

We hold that the language of the [Railway Labor] Act . . . read in the light of the purposes of the Act, expresses the aim of Congress to impose on the bargaining representative ... the duty to exercise fairly the power conferred upon it in behalf of all those for whom it acts . . . . Id. at 202-03.

33. The role of the majority union under the Railway Labor Act as exclusive bargaining agent for all meunbers of the bargaining unit was recognized by the Supreme Court in Order of Ry. Telegraphers v. Railway Express Agency, Inc., 321 U.S. 342, 347 
obligation to treat all members of the bargaining umit fairly and equally. The standard announced by the Steele Court required the union to represent members of the bargaining umit "without hostile discrimination, fairly, impartially, and in good faith."34 The racial discrimination practiced by the union in Steele clearly breached this duty of fair representation. ${ }^{35}$

Apart from the racial discrimination context, however, the extent of the union's duty remained unclear until Vaca $v$. Sipes. ${ }^{36}$ There the Supreme Court defined more clearly the union behavior which could breacls its duty:

A breach of the statutory duty of fair representation occurs only when a union's conduct toward a member of the collective bargaining unit is arbitrary, discriminatory, or in bad faith . . . .

Though we accept the proposition that a union may not arbitrarily ignore a ineritorious grievance or process it in a perfunctory fashion, we do not agree that the individual employee has an absolute right to have his grievance taken to arbitration regardless of the provisions of the applicable collective bargaining agreement. ${ }^{37}$

The "arbitrary, discriminatory, or in bad faith" standard established in Vaca sets a high threshold requirement for the allegation of a breach of the umion's duty and leaves the union with wide discretion to decide in good faith whether to prosecute an individual's grievance. Yet, the Court's use of the words "arbitrary" and "perfunctory," without explaining their meaning, left the Vaca holding open to interpretation and led some courts and commentators to conclude that the Court had abandoned the requirement of bad faith and hostility. ${ }^{38}$ It would seem, how-

(1944). See also J.I. Case Co. v. N.L.R.B., 321 U.S. 332 (1944) (recognizing the same proposition with respect to the National Labor Relations Act).

34. 323 U.S. at 204.

35. Subsequent to Steele, racial discrimination in the handling of grievances was held to violate the union's duty of fair representation in Conley v. Gibson, 355 U.S. 41 (1957); and in Brotherhood of Ry. Trainmen v. Howard, 343 U.S. 768 (1952), racial discrimination by one union practiced against members of another union was held to violate the duty.

36. 386 U.S. 171 (1967).

37. Id. at $190-91$.

38. In Griffin v. UAW, 469 F.2d 181 (4th Cir. 1972), the court stated:

The repeated references in Vaca to "arbitrary" union conduct reflected a calculated broadening of the fair representation standard. . . . Without any hostile motive of discrimination and in complete good faith, $a$ union may nevertheless pursue a course of action or inaction that is so unreasonable and arbitrary as to constitute a violation of the duty of fair representation. Id. at 183.

The court also noted, however, that "negligence in handling grievances has not been identified as breaching the union's duty of fair representation." Id. See Retana v. Apartment Operators Local 14, 453 F.2d 1018, 1023 n.8 (9th Cir. 1972); Tobias, A Plea 
ever, that the Court used "arbitrary" and "perfunctory" to describe prohibited union notivations and attitudes, rather than to prohibit good faith union behavior which results in arbitrary or perfunctory treatment of the eniployee. Read in its entirety, the language of the Vaca Court supports the conclusion that only intentional, conscious union conduct can breach its duty. This conclusion is further strengthened by the subsequent case of Amalgamated Association of Motor Coach Employees v. Lockridge. ${ }^{39}$ There the Court, in dismissing an eniployee's assertion that he was suing his union to rectify a breach of the duty of fair representation, stated with force and clarity the requisites of a union breach of the duty of fair representation and, for the first time, specifically excluded the possibility of an unintentional breach:

The duty of fair representation was judicially evolved ... to enforce fully the important principle that no individual union member may suffer invidious, hostile treatment at the hands of the majority of his coworkers ... . [The doctrine] carries with it the need to adduce substantial evidence of discrimination that is imtentional, severe, and unrelated to legitimate union objectives .... [T] [Te very distinction . . . between honest, mistaken conduct, on the one hand, and deliberate and severely hostile and irrational treatment on the other, needs strictly to be maintained. ${ }^{40}$

Despite the clear language of Lockridge, there remains pressure to expand the duty of fair representation to proscribe unintentional and neghgent union conduct. ${ }^{41}$

for the Wrongfully Discharged Employee Abandoned by His Union, 41 U. CIN. L. REv. 55, 73-77 (1972). But see Williams v. General Foods, 492 F.2d 399, 405 (7th Cir. 1974); Jackson v. Trans World Airline, Inc., 457 F.2d 202, 204 (2d Cir. 1972) ("Something akin to factual malice is necessary to establish a breach of the duty of fair representation").

39. 403 U.S. 274 (1971).

40. Id. at 301 .

41. Lockridge was an embarrassing decision for the proponents of an expanded duty of fair representation who found a liberalized standard in the Vaca opinion. See note 38 supra. The Lockridge standard is considerably more stringent than the reading given Vaca by the courts and commentators favoring such a hberalization, yet there is nothing in Lockridge to indicate that the Court intended to alter the Vaca standard. Thus, the Lockridge standard implicitly refutes the existence of a liberalized standard in Vaca.

One writer has attempted to resolve this difficulty by characterizing the Lockridge Court's discussion of the duty of fair representation as "ringing dictuin" which exhibits a "lack of care in using language and analysis" and therefore "must be somewhat discounted." Bryson, A Matter of Wooden Logic: Labor Law Preemption and Individual Rights, 51 Texas L. REv. 1037, 1070 (1973). Even if the Court's discussion was dictum, however, it should be considered a clear signal to the lower courts that they have been misreading Vaca. Furthermore, a careful reading of Lockridge indicates that the Court's analysis of the duty of fair representation was essential to the lolding. Lockridge obtained a judgment in state court against his union. The Supreme Court granted 
The Second Circuit in Schum v. South Buffalo Railway expanded the definition of a union's duty of fair representation to include the situation where the interests of a union nnember are impaired by unintentional union mishandling of his grievance. The facts of the case presented a compelling and sympathetic picture of a umon nember who found himself without a remedy through little or no fault of his own. However, the vehicle chosen by the court to enable Schum to sue his employer for wrongful discharge-a breach of the union's duty of fair representation-was supported by neither precedent nor policy. In Vaca, the Supreme Court, while admittedly creating some ambiguity by its uncertaim use of the words "arbitrary" and "perfunctory," seemed clearly to intend to maintaim the Steele requirement of hostile or discriminatory union conduct. Subsequently, in Lockridge, the Court described the type of union conduct which will breach the duty in such terms as "invidious," "liostile," "intentional," "severe," and "deliberate," ${ }^{42}$ The duty is not breached, on the other hand, by "honest mistaken conduct." 43 While acknowledging that the Vaca standard left some interpretational questions unanswered, ${ }^{44}$ the court in Schum iguored the

certiorari to determine whether the jurisdiction of the state court was preempted by the exclusive jurisdiction of the National Labor Relations Board. 403 U.S. at 276-77. Lockridge argued that his case came within a recognized exception to the preeinption doctrine for actions to redress a breach of the duty of fair representation. 1d. at 298. Thus, to decide whether the general rule of preemption applied, the Court had to determine whether the exception applied because Lockridge neither alleged nor proved that his union engaged in the type of conduct which would breach the duty of fair representation. Id. at 299-300. It seeins clear that if the Court had found that the honest, mistaken union behavior in Lockridge constituted a breach of the duty of fair represeutation, it would have been compelled to uphold rather than reverse the Idaho Supreme Court. Therefore, to classify the Court's analysis as dictum is fallacious.

Another writer has suggested that the Lockridge Court sinply misread Vaca. See Clark, The Duty of Fair Representation: A Theoretical Structure, 51 Texas I. Rev. 1119,1125 (1973). The logic behind this author's conclusion is as follows: (1) Vaca established a broad standard for identifying a breach of the duty of fair representation; (2) Lockridge posited a much more stringent standard, yet the Court gave no indication that it meaut to make substantive changes in the duty of fair represeutation; (3) therefore, the Lockridge Court misread Vaca. Id. at 1125-26. The flaw in this logic stems from its initial premise. The Court did not intend to establish a broad standard in Vaca. Lockridge merely reiterated the Vaca standard in language that could not be misconstrued by the lower courts. The suggestion by Ms. Clark that the lower courts should iguore Lockridge unless and until the Supreme Court bases a duty of fair representation holding on it, id. at 1126, is misguided and mischievous. Decisions of the Supreme Court become binding upon the lower courts when handed down, not the first time they are cited in a subsequent decision of the Court.

42. 403 U.S. at 301.

43. Id.

44. The Schum court observed that the Vaca Court did not define "precisely the duty of fair representation." 496 F.2d at 330. 
subsequent clarification in Lockridge $e^{45}$ and assumed, without discussion, that no showing of intentionally hostile, discriminatory, or indivious union intent was necessary. The court imphicitly bound the union to a duty of due care and diligence. This assumption clearly expanded the parameters of the duty of fair representation in contradiction to its previous definition by the Supreme Court.

Further weight is lent to the conclusion that the Schum court impermissibly expanded the duty of fair representation by an examination of the policy considerations which underly the decisions of the Suprene Court in this area. The Court has discerned the intent of Congress to preserve and protect the position of the union as the bargaining representative and to intrude as seldonr as possible in internal union affairs. ${ }^{46}$ Where the courts are called upon to consider a union's handling of a grievance, this interpretation of congressional intent nranifests itself in a noninterventionist judicial pose which allows a union wide discretion and a presumption of reasonableness in the handling and settling of grievances. As the Court made clear in Vaca, a union member (or other nieniber of the bargaining unit) has no absolute right to have his grievance taken to arbitration. ${ }^{47}$ The union nray make its own decision as to the merits of the grievance and may even settle a meritorious grievance against the employee, subject only to the requirement of the duty of fair representation that the union's conduct not be arbitrary, discriminatory, or in bad faitli. ${ }^{48}$ Thus, the duty of fair representation, as it has been given substance by the Court that created it, is not intended to authorize judicial oversight of the manner in which a union handles employee grievances or other internal affairs, unless the union behavior is wrongfully inotivated.

45. By ignoring Lockridge, the Second Circuit, perhaps unwittingly, followed the advice of Ms. Clark. See note 41 supra. At least three other circuits, however, by citing Lockridge with approval, have recognized that the Lockridge standard is to be applied in determining whether a union breached its duty of fair representation. See Dente v. International Organization of Masters, Local 90, 492 F.2d 10, 12 n.3 (9th Cir. 1973), cert. denied, 94 S. Ct. 2607 (1974); Wernet v. Amalgamated Meat Cutters, 484 F.2d 403, 405 (6th Cir. 1973); Buzzard v. Local 1041, Int'1 Ass'n of Machinists, 480 F.2d 35, 40 (9th Cir. 1973); Patterson v. Local 513, Motion Picture Operators, 446 F.2d 205, 208 (10th Cir. 1971).

46. See, e.g., N.L.R.B. v. Allis-Chalmers Mfg. Co., 388 U.S. 175, 180-90 (1967); Ford Motor Co. v. Huffman, 345 U.S. 330, 337-39 (1953).

47. 386 U.S. at 190-95.

48. The Vaca Court enumerated several of the purposes served by deference to the union in the handling of grievauces: elimination of frivolous grievances, consistent treatment of grievances by the union, consisteut interpretation of the collective bargaining agreement, reduction in time and money spent in the grievance process, and strengthening the union as statutory agent of the employees and as co-author of the collective agreement. Id. at 191-92. 
The facts in Schum, where the union apparently simply missed the appeal deadline, do not present as persuasive an argument for judicial deference as does a case such as Vaca, where the union consciously decided to go no further with the member's grievance. Nonetheless, the policies underlying judicial deference to umons argue against fimding a breach of the umion's duty. The care and efficiency with which a union handles grievances is undoubtedly in part a matter of allocation of limited time and money. Holding unions liable for honest mistakes and oversights would require unions to reallocate their limited resources to the detriment of other important functions as representative of the bargaining unit. Viewed in the context of the congressional preference for nonintervention in internal union affairs and of the judicial deference to union grievance-handling where there is no evidence of improper union motivation, the Schum lolding seems clearly wrong.

Another undesirable result of the Schum decision is that the umion bears little or no liability for its breach, ${ }^{49}$ whereas the employer may be seriously disadvantaged. The Schum decision suspends the operation of the contractually agreed statute of limitations, thus forcing the employer to defend an action which it could reasonably have expected to expire when no appeal was filed with the Adjustment Board within the stipulated six month period. ${ }^{50}$ Further, every time a court excuses an employee's failure to pursue his administrative reniedy before the Adjustment Board, the expectation of the employer that the administrative forum will be exclusive is defeated, thus penalizing the employer for the union's imisconduct. While this anomalous result is necessary to protect the employee when the umion acts in a hostile or discriminatory fashion, the frequency of its occurrence should not be multiplied by extending the duty of fair representation, and hence the avoidance of the statutory administrative remedy, to cases of unintentional umion behavior.

The basis suggested by the court for its decision-reliance-is clearly not a satisfactory theoretical foundation for an expanded definition of the duty of fair representation. Virtually all union members who

49. See note 10 supra.

50. It can be argued that the employer has really lost nothing by the frustration of the statute of limitations, since the union's failure to file a timely appeal was a windfall which saved the employer the expense of defending before the Adjustment Board. Nonetheless, from the employer's point of view, the failure of the union to appeal could reasonably have been interpreted as bringing the entire grievance to a close, and there is a real possibility that revival of the employee's barred complaint in a federal court action will prejudice the employer's ability to gather evidence. The employer may have failed to preserve testimonial or documentary evidence which would have been available if the appeal had been made in a timely nanner. 
wish to protest an action of their employer rely upon their union, ${ }^{51}$ yet Vaca clearly holds that a union may act contrary to what the grievant beheves to be his best interest, as long as the union's action is not arbitrary, discriminatory, or in bad faith. ${ }^{52}$ The use of reliance to identify a breach of the duty of fair representation is particularly inapt under the Railway Labor Act where a member's reliance on his union is merely optional rather than compulsory. The Act does not allow unions to compel individual members to rely on them, but instead allows a member the option of pursuing his remedy before the Adjustment Board independently of his union..$^{53}$

The Schum court's use of reliance does suggest, however, a possible alternative analysis by which the court could have reached the result it desired without the impermissible expansion of the duty of fair representation which it in fact accomplished. To revive Schum's right of action against the railroad for wrongful discharge, the court found it necessary to avoid the exhaustion requirement. Of the exceptions to the exhaustion requirement posited in Vaca, only the breach of the duty of fair representation is remotely relevant, which undoubtedly explains its use. Yet in the subsequent case of Glover v. St. Louis-San Francisco Railway, ${ }^{54}$ the Supreme Court added another to Vaca's list of exceptions to the exhaustion requirement and seemed to invite the recognition of still further exceptions. ${ }^{55}$ Thus, the Schum court could have created a new exception and held that an employee need not exhaust his contractual and administrative remedies where he has the right to pursue his grievance on his own, but his union undertakes to do it for him and then fails to notify him that it is, for whatever reason, abandoning his grievance, thus preventing the employee from pursuing it in his own right. A narrow holding of this purport would have furnished the Schum court the exception to exhaustion which it needed without a wholesale and unjustified expansion of the duty of fair representation and the importation of the alien concept of reliance into this area of labor law.

51. Under the National Labor Relations Act, the union and employer can compel employees to grieve through the union. Under the Railway Labor Act this is not permitted. See note 28 supra. As a practical matter, most aggrieved employees will grieve through their union because the union will usually possess greater wealth, experience, and influence with employers than the employee will have, thus increasing the chances of success.

52. 386 U.S. at 190-93.

53. See note 28 supra.

54. 393 U.S. 324 (1969).

55. Id. at 330 . See note 30 supra. 